\title{
Factors affecting the pharmacokinetics and pharmacodynamics of PEGylated liposomal irinotecan (IHL-305) in patients with advanced solid tumors [Corrigendum]
}

Wu H, Infante JR, Keedy VL, et al. Int J Nanomedicine. 2015:10;1201-1209.

On page 1208, Disclosure section, "The authors report no conflicts of interest in the work" has been updated since publication and should read "Dr Burris reports a payment to his institution, Sarah Cannon Research Institute, from Yakult Honsha during the conduct of the study; grants to his institution for studies on which he served as Principal Investigator outside of the submitted work from the following companies: Acerta Pharma, Agios, Amgen, Amplimmune, Array BioPharma, AstraZeneca, BIND Therapeutics, BioMed Valley Discoveries, Inc., Celgene, eFFECTOR Therapeutics, Eli Lilly, Exelixis, Genentech, GlaxoSmithKline, Immunocore, Intellikine, Janssen, Loxo Oncology, MacroGenics, MedImmune, Medivation, Millennium Pharmaceuticals, Novartis, Pfizer, Sanofi, Seattle Genetics, Stem CentRx, Tesaro, TG Therapeutics, Verastem, and Vertex Pharmaceuticals. Dr Burris reports consulting fees paid to his institution for his services from the following companies: Bristol Myers Squibb, NipponKayaku, Intellisphere, Novartis, Genentech, BIND Therapeutics, and AstraZeneca. Dr Burris reports non-financial support to his institution from AstraZeneca, Celgene, Eli Lilly, GlaxoSmithKline, Janssen, Millennium, Novartis, Sanofi, Amgen, Hoffman-LaRoche, Ventana, Grifols USA, and Astellas Pharmaceuticals. Dr Keedy reports clinical trial management costs from Yakult Honsha during the conduct of the study; grants outside the submitted work from Abraxis and personal fees outside the submitted work from Ziopharm. Dr Keedy also reports other financial sponsorship outside the submitted work to her institution, Vanderbilt University, from the following companies: Amgen, Ariad, Genentech, Janssen Pharmaceutical Companies of Johnson \& Johnson, Merrimack, Nereus, Novartis, Pfizer, Threshold, U3 Pharma and Ziopharm. Dr Chan reports a payment to her institution, Vanderbilt University, from Yakult Honsha during the conduct of the study and outside the submitted work has served as an advisory board member for Amgen. Dr Bendell reports research funding to her institution, Sarah Cannon Research Institute, from Gilead, Genentech a member of the Roche group, Bristol-Myers Squibb, Five Prime, Eli Lilly, Merck, MedImmune, Celgene, EMD Serono, Taiho, Macrogenics, GlaxoSmithKline, Novartis, OncoMed, Leap Therapeutics, TG Therapeutics, AstraZeneca, Boehringer Ingelheim (BI), Daiichi Sankyo, Bayer, Incyte, Apexigen, Koltan, SynDevRex, Forty Seven, AbbVie, Array, Onyx, Sanofi, Takeda, Eisai, Celldex, Agios, Cytomx, Nektar, ARMO BioSciences Inc, Boston Biomedical, Ipsen, Merrimack, Tarveda, Tyrogenex, Oncogenex, Marshall Edwards, Pieris, Mersana, Calithera, Blueprint, Evelo, Forma Therapeutics, Merus, Jacobio, Effecto, Novocare, Arrys, Tracon, Sierra, Innate, Arch Oncology, Prelude Oncology, Unum Therapeutics, Vyriad, Harpoon, ADC Therapeutics, Amgen, Pfizer, Millennium, Imclone, Acerta Pharma, Rgenix, and Bellicum. Dr Bendell reports consulting/advisory fees paid to her institution for her services from the following companies: Gilead, Genentech a member of the Roche group, Bristol-Myers Squibb, Five Prime, Eli Lilly, Merck, MedImmune, Celgene, Taiho, Macrogenics, GlaxoSmithKline, Novartis, OncoMed, LEAP, TG Therapeutics, AstraZeneca, BI, Daiichi Sankyo, Bayer, Incyte, Apexigen, Array, Sanofi, ARMO BioSciences Inc, Ipsen, Merrimack, Oncogenex, FORMA, Arch Oncology, Prelude Therapeutics, Phoenix Bio, Cyteir, Molecular Partners, Innate, Torque, Tizona, Janssen, Tolero, TD2 (Translational Drug Development), Amgen, Seattle Genetics, Moderna Therapeutics, Tanabe Research Laboratories, Beigene, Continuum Clinical, Agois, and Kyn. Dr. Bendell also received food/beverage and travel allowances from Gilead, Genentech a member of Roche group, Bristol-Myers Squibb, Eli Lilly, Merck, MedImmune, Celgene, Taiho, Novartis, OncoMed, BI, ARMO BioSciences Inc, Ipsen, Oncogenes, and FORMA. 
Dr Rothenberg reports he received funding from Yakult Honsha and he is currently an employee of Pfizer. Dr Zamboni reports fundings from Yakult Pharmaceuticals to perform the pharmacokinetic studies and he works as a consultant for Yakult Honsha. The authors report no other conflicts of interest in this work".

\section{Publish your work in this journal}

The International Journal of Nanomedicine is an international, peerreviewed journal focusing on the application of nanotechnology in diagnostics, therapeutics, and drug delivery systems throughout the biomedical field. This journal is indexed on PubMed Central, MedLine, CAS, SciSearch ${ }^{\circledR}$, Current Contents ${ }^{\circledR} /$ Clinical Medicine,
Journal Citation Reports/Science Edition, EMBase, Scopus and the Elsevier Bibliographic databases. The manuscript management system is completely online and includes a very quick and fair peer-review system, which is all easy to use. Visit http://www.dovepress.com/ testimonials.php to read real quotes from published authors. 